\title{
Sphingobium vermicomposti sp. nov., isolated from vermicompost
}

\author{
Ivone Vaz-Moreira, ${ }^{1,2}$ Cátia Faria, ${ }^{2}$ Ana R. Lopes, ${ }^{2}$ Liselott Svensson, ${ }^{3}$ \\ Enevold Falsen, ${ }^{3}$ Edward R. B. Moore, ${ }^{3}$ António C. Silva Ferreira, ${ }^{1}$ \\ Olga C. Nunes ${ }^{2}$ and Célia M. Manaia ${ }^{1}$ \\ ${ }^{1}$ Escola Superior de Biotecnologia, Universidade Católica Portuguesa, 4200-072 Porto, Portugal \\ ${ }^{2}$ LEPAE - Departamento de Engenharia Química, Faculdade de Engenharia, Universidade do Porto, \\ 4200-465 Porto, Portugal \\ ${ }^{3}$ CCUG - Culture Collection University Göteborg, Sahlgrenska University Hospital, Sahlgrenska \\ Academy, University of Göteborg, S-41346 Göteborg, Sweden
}

Correspondence

Célia M. Manaia cmmanaia@esb.ucp.pt

\begin{abstract}
Strain VC-230 ${ }^{\top}$ was isolated from homemade vermicompost produced from kitchen waste. The isolate was a Gram-negative-staining, catalase- and oxidase-positive, motile rod-shaped bacterium able to grow at $15-37{ }^{\circ} \mathrm{C}$ and $\mathrm{pH} 6-8$. On the basis of $16 \mathrm{~S}$ rRNA gene sequence analysis, strain $\mathrm{VC}-230^{\top}$ was determined to belong to the family Sphingomonadaceae by its clustering with type strains of the genus Sphingobium, with Sphingobium chlorophenolicum ATCC $33790^{\top}(97.7 \%)$ and Sphingobium herbicidovorans DSM $11019^{\top}(97.4 \%)$ as its closest neighbours. The polar lipid pattern, the presence of spermidine and ubiquinone 10 , the predominance of the cellular fatty acids $\mathrm{C}_{18: 1} \omega 7 c / 9 t / 12 t, \mathrm{C}_{16: 1} \omega 7 c$ and $\mathrm{C}_{16: 0}$ and the $\mathrm{G}+\mathrm{C}$ content of the genomic DNA supported the affiliation of this organism to the genus Sphingobium. The phylogenetic, chemotaxonomic, phenotypic and DNA-DNA hybridization analyses verify that strain VC- $230^{\top}$ represents a novel species, for which the name Sphingobium vermicomposti sp. nov. is proposed. The type strain is VC- $230^{\top}\left(=\right.$ CCUG $55809^{\top}=$ DSM $\left.21299^{\top}\right)$.
\end{abstract}

The status of the genus Sphingomonas has been the subject of debate (Takeuchi et al., 2001; Yabuuchi et al., 2002); Takeuchi et al. (2001) proposed the division of the genus into four genera, mainly on the basis of $16 \mathrm{~S}$ rRNA gene sequence analysis but also according to chemotaxonomic and phenotypic traits. One of the newly proposed genera, Sphingobium, currently comprises 15 species (Euzéby, 1997). This paper describes the phylogenetic, phenotypic and chemotaxonomic properties of a bacterium, designated $\mathrm{VC}-230^{\mathrm{T}}$, isolated from homemade kitchen-refuse vermicompost produced with the earthworm Eisenia fetida (Vaz-Moreira et al., 2008).

Vermicomposting is a method for decomposing organic residues into a humus-like product through the digestive process of an earthworm, usually Eisenia fetida. Unlike other composting processes, decomposition is achieved by the earthworm's digestive enzymes and, presumably, symbiotic bacteria, and does not involve a thermal phase (Epstein, 1997). Strain VC-230 ${ }^{\mathrm{T}}$ was isolated and purified by subculturing on plate count agar (PCA; Pronadisa) from a sample in which total heterotrophic bacterial counts were of the order of $10^{6}$ c.f.u. (g compost) ${ }^{-1}$. Among the isolates

The GenBank/EMBL/DDBJ accession number for the 16S rRNA gene sequence of strain $\mathrm{VC}-230^{\top}$ is $\mathrm{AM} 998824$. recovered from this sample, strain $\mathrm{VC}-230^{\mathrm{T}}$ presented a unique random amplified polymorphic DNA profile (VazMoreira et al., 2008); subsequent analysis of the 16S rRNA gene sequence gave evidence that this organism is affiliated to the family Sphingomonadaceae.

Strain VC- $230^{\mathrm{T}}$ was cultured on PCA at $30{ }^{\circ} \mathrm{C}$ and stored at $-80{ }^{\circ} \mathrm{C}$ in modified Luria-Bertani broth with $15 \%(\mathrm{v} / \mathrm{v})$ glycerol (Vaz-Moreira et al., 2007). Colony characteristics, cell morphology, Gram-stain reaction, cytochrome $c$, oxidase and catalase activity and motility and presence of flagella were analysed following the methodologies of Murray et al. (1994) and Smibert \& Krieg (1994). Unless otherwise stated, all biochemical and physiological tests were performed as described previously (Vaz-Moreira et al., 2007). Biochemical and nutritional tests were performed using the API 20E, API 20NE, API ZYM and API 50CH strips (bioMérieux), according to the manufacturer's instructions, except for the use of mineral medium B (Barreiros et al., 2003) supplemented with $4 \mathrm{mM}$ $\left(\mathrm{NH}_{4}\right)_{2} \mathrm{SO}_{4}$ with the API $50 \mathrm{CH}$ strip, to test for assimilation of individual carbon sources. Antibiotic susceptibility was assayed as described by Ferreira da Silva et al. (2006). The ability to degrade hexachlorocyclohexane (Sigma) was tested at $30{ }^{\circ} \mathrm{C}$ in Luria-Bertani 
medium supplemented with $4 \mathrm{mg}$ hexachlorocyclohexane $1^{-1}$. Hexane (Merck) extracts of culture supernatants were analysed using a Varian CP-3800 gas chromatograph equipped with a Varian Saturn 1200L triple quadrupole MS/MS mass selective detector and GC-MS workstation software, version 6.8. The internal standard was 3-octanol (Fluka).

Determination of the $\mathrm{G}+\mathrm{C}$ content of genomic DNA and the respiratory quinones was done as described previously by Vaz-Moreira et al. (2007), using the methods of Mesbah et al. (1989) and Tindall (1989), respectively. Polar lipids were extracted and examined as described previously by Manaia et al. (2004). Whole-cell fatty acid methyl esters were analysed from cultures grown on R2A minimal medium (Difco) at $30{ }^{\circ} \mathrm{C}$, according to a variation of the MIDI Sherlock Microbial Identification System (http:// www.ccug.se/pages/cfanew.pdf). Polyamines were extracted as described by Hamana et al. (1994) and analysed by LCMS. Spermidine was detected using a Varian LC-MS 1200L detector coupled with an SS HPLC column $(100 \times 20 \mathrm{~mm}$; Varian) and a Pursuit 5C18 (Varian) guard column with a mobile phase of water/methanol $(50: 50, \mathrm{v} / \mathrm{v}$; (Romil) in $0.1 \mathrm{M}$ formic acid (Merck).

The sequence of the 16S rRNA gene was determined after PCR amplification as described by Ferreira da Silva et al. (2007). The 16S rRNA gene sequence was compared with others available in the GenBank database using the FASTA sequence similarity search tool of EMBL-EBI (http:// www.ebi.ac.uk). Phylogenetic analysis was conducted using the BioNumerics software platform (version 5.1; Applied Maths). Estimates of sequence relatedness were based on the model of Jukes \& Cantor (1969) and the dendrogram was created using the neighbour-joining method.
Maximum-parsimony and maximum-likelihood methods were used to assess tree stability. Non-homologous and ambiguous nucleotide positions were excluded from the calculations. Genomic DNA-DNA relatedness analyses were performed using the hybridization protocols described by Urdiain et al. (2008).

A comprehensive phylogenetic analysis of 16S rRNA gene sequences using neighbour-joining, maximum-likelihood and maximum-parsimony methods, which included sequences from the type strains of all species of the genera Sphingomonas and Sphingobium, provided evidence that strain VC- $230^{\mathrm{T}}$ clusters with the genus Sphingobium (Takeuchi et al., 2001). Sphingobium chlorophenolicum ATCC $33790^{\mathrm{T}}$ and Sphingobium herbicidovorans DSM $11019^{\mathrm{T}}$ were the closest neighbours (97.7 and 97.4\% similarity, respectively) and the type strain of the type species of Sphingobium, Sphingobium yanoikuyae IFO $15102^{\mathrm{T}}$, exhibited $96.3 \%$ similarity. A tree estimating the phylogenetic relationships between strain $\mathrm{VC}-230^{\mathrm{T}}$ and the type strains of Sphingobium and Sphingomonas species is shown in Fig. 1.

Strain VC- $230^{\mathrm{T}}$ and the type strains of the most closely related species, Sphingobium chlorophenolicum CCUG $56399^{\mathrm{T}}$ and Sphingobium herbicidovorans CCUG $56400^{\mathrm{T}}$, were analysed and compared at the phenotypic level (Table 1). Strain VC- $230^{\mathrm{T}}$ was observed to possess ubiquinone $10(\mathrm{Q}-10)$ as the major respiratory quinone $(96 \%)$. The polar lipid pattern of strain VC-230 ${ }^{\mathrm{T}}$ (Fig. 2) included phosphatidylethanolamine, phosphatidylmonomethylethanolamine, phosphatidylglycerol, diphosphatidylglycerol, phosphatidyldimethylethanolamine, phosphatidylcholine and a sphingoglycolipid. Similar patterns were observed for Sphingobium chlorophenolicum CCUG $56399^{\mathrm{T}}$

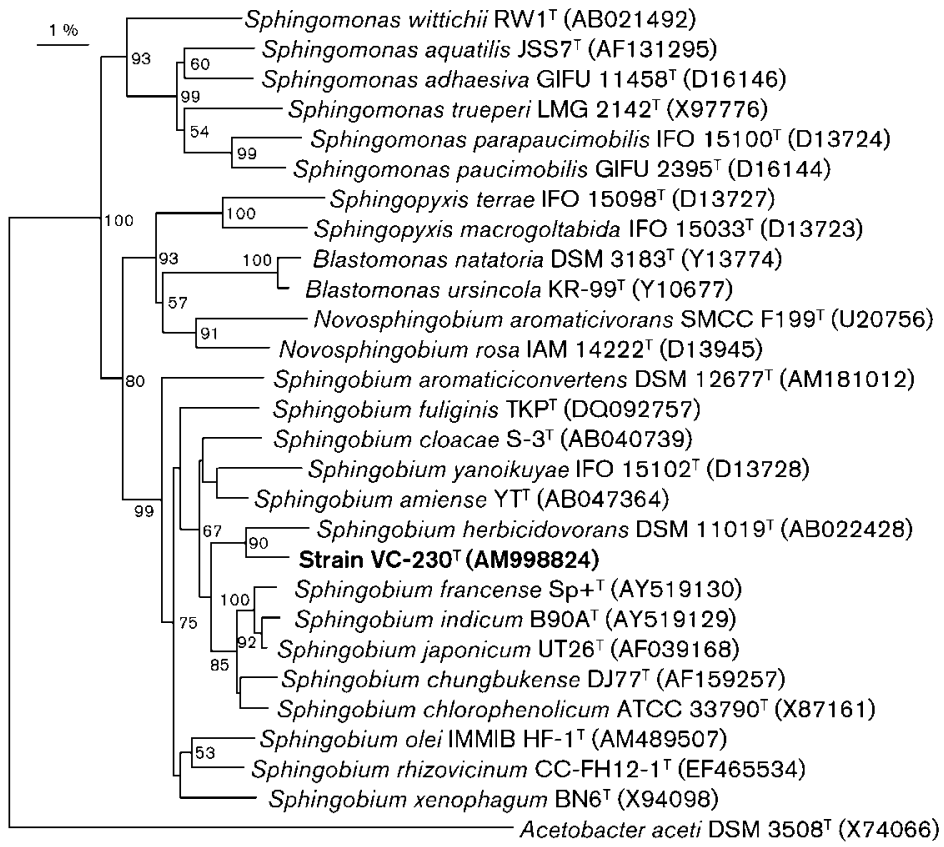

Fig. 1. Phylogenetic tree derived from $16 \mathrm{~S}$ rRNA gene sequence analysis showing the relationship of strain $\mathrm{VC}-230^{\top}$ with members of the genera Sphingobium and Sphingomonas. The tree was generated by the neighbour-joining method. Bootstrap values $(>50 \%)$ based on 1000 resamplings are shown at branch points. The sequence of Acetobacter aceti DSM $3508^{\top}$ was used as an outgroup. Bar, 1 substitution per 100 nucleotide positions. 
Table 1. Distinctive characteristics of strain $\mathrm{VC}-230^{\top}$ and type strains of closely related species

Strains: 1, Sphingobium vermicomposti sp. nov. VC-230 ${ }^{\mathrm{T}}$; 2, Sphingobium chlorophenolicum $\mathrm{CCUG} 56399^{\mathrm{T}}$; 3 , Sphingobium herbicidovorans CCUG $56400^{\mathrm{T}}$. Data were taken from this study unless indicated. All strains were positive for oxidase, aesculin hydrolysis, assimilation of glucose and production of $\beta$-glucosidase, esterase (C4), esterase lipase (C8), leucine and valine arylamidases, trypsin, acid and alkaline phosphatases and naphthol-AS-BI-phosphohydrolase. All strains were negative for Gram-staining, citrate utilization, $\mathrm{H}_{2} \mathrm{~S}$, indole and acetoin production, gelatin hydrolysis, nitrate reduction, glucose fermentation, oxidation of D-glucose, D-mannitol, inositol, D-sorbitol, sucrose and melibiose, assimilation of D-mannose, D-mannitol, $N$-acetylglucosamine, maltose, caprate, citrate, phenyl acetate, glycerol, erythritol, D- and L-arabinose, D-ribose, D- and Lxylose, adonitol, methyl $\beta$-D-xylopyranoside, D-fructose, L-sorbose, dulcitol, inositol, methyl $\alpha$-D-mannopyranoside, methyl $\alpha$-D-glucopyranoside, amygdalin, salicin, melibiose, sucrose, trehalose, inulin, melezitose, raffinose, starch, glycogen, xylitol, gentiobiose, turanose, D-lyxose, D-tagatose, D- and L-fucose, D- and L-arabitol, potassium gluconate, 2-ketogluconate and 5-ketogluconate and production of arginine dihydrolase, lysine and ornithine decarboxylases, urease, tryptophan deaminase, lipase (C14), cystine arylamidase, $\alpha$-galactosidase, $\beta$-glucuronidase, $N$-acetyl- $\beta$ glucosaminidase, $\alpha$-mannosidase or $\alpha$-fucosidase. + , Positive; w, weak; - , negative; ND, no data available.

\begin{tabular}{|c|c|c|c|}
\hline Characteristic & 1 & 2 & 3 \\
\hline Colony colour & Yellow & Yellow & Yellow with melanin production \\
\hline Motility & + & - & + \\
\hline \multicolumn{4}{|l|}{ Oxidation (API 20E) of: } \\
\hline Amygdalin & - & + & - \\
\hline L-Rhamnose & - & - & + \\
\hline \multicolumn{4}{|l|}{ Assimilation of: } \\
\hline Cellobiose & - & + & - \\
\hline D-Galactose & + & - & + \\
\hline Lactose & + & - & - \\
\hline L-Rhamnose & + & - & + \\
\hline$\alpha$-Chymotrypsin & - & + & - \\
\hline$\beta$-Galactosidase & + & - & - \\
\hline$\alpha$-Glucosidase & - & + & + \\
\hline DNA G $+C$ content $(\mathrm{mol} \%)$ & 62 & $65^{c}$ & ND \\
\hline
\end{tabular}

${ }^{\star}$ Data taken from: $a$, Nohynek et al. (1996); b, Zipper et al. (1997); c, Fujii et al. (2001).

and Sphingobium herbicidovorans CCUG $56400^{\mathrm{T}}$, although the unknown phosphoglycolipid was not detected in these strains. This polar lipid composition is in agreement with those observed in sphingomonads of the genera Sphingobium and Sphingomonas (Busse et al., 1999). The predominant fatty acids were $\mathrm{C}_{16: 1} \omega 7 c, \mathrm{C}_{16: 0}$ and $\mathrm{C}_{18: 1} \omega 7 c / 9 t / 12 t$, which comprised over $80 \%$ of the total (Table 2). The genomic DNA G $+\mathrm{C}$ content for strain VC$230^{\mathrm{T}}$ was determined to be $62.2 \pm 0.3 \mathrm{~mol} \%$. These characteristics confirmed the inclusion of strain VC- $230^{\mathrm{T}}$ with the sphingomonads and the presence of the polyamine spermidine indicated that the strain belongs to the genus Sphingobium (Takeuchi et al., 2001). These data were in agreement with the phylogenetic analysis based on $16 \mathrm{~S}$ rRNA gene sequences.

Because of the high 16S rRNA gene sequence similarities between strain VC-230 ${ }^{\mathrm{T}}$ and Sphingobium chlorophenolicum ATCC $33790^{\mathrm{T}}(97.7 \%)$ and Sphingobium herbicido- vorans DSM $11019^{\mathrm{T}}(97.4 \%)$, genomic DNA-DNA relatedness values were determined between strain VC$230^{\mathrm{T}}$ and Sphingobium chlorophenolicum CCUG 56399 ${ }^{\mathrm{T}}$ (36\%, mean of duplicate measurements of 29 and $42 \%$ ) and Sphingobium herbicidovorans CCUG $56400^{\mathrm{T}}(49 \%$, mean of 47 and $51 \%$ ). These values confirmed that strain VC- $230^{\mathrm{T}}$ represents a distinct and novel species of the genus Sphingobium. Such results are in agreement with the evidence given by Stackebrandt \& Ebers (2006), wherein strains that show less than $98.5 \% 16 \mathrm{~S}$ rRNA gene sequence similarity present DNA-DNA reassociation values lower than $70 \%$, thus excluding the possibility of inclusion in these species as long as strain $\mathrm{VC}-230^{\mathrm{T}}$ exhibits distinctive phenotypic features. In fact, when the three strains were tested concurrently, strain $\mathrm{VC}-230^{\mathrm{T}}$ could be distinguished from Sphingobium chlorophenolicum CCUG $56399^{\mathrm{T}}$ and Sphingobium herbicidovorans CCUG $56400^{\mathrm{T}}$ on the basis of several morphological, biochemical and physiological traits (Table 1). Furthermore, after growth under the same 


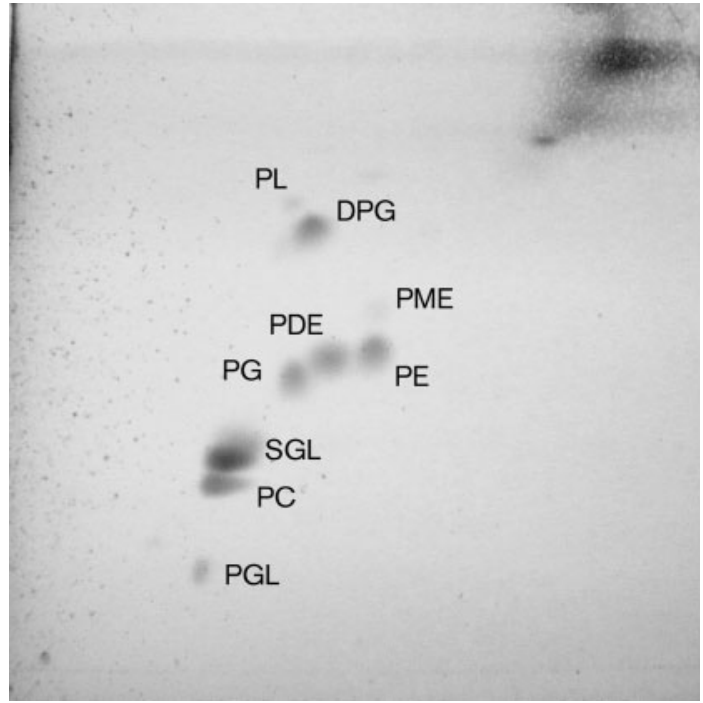

Fig. 2. Polar lipid pattern of strain $V C-230^{\top}$. DPG, Diphosphatidylglycerol; PC, phosphatidylcholine; PDE, phosphatidyldimethylethanolamine; $\mathrm{PE}$, phosphatidylethanolamine; PG, phosphatidylglycerol; PGL, unidentified phosphoglycolipid; PL, unidentified phospholipid; PME, phosphatidylmonomethylethanolamine; SGL, sphingoglycolipid.

cultivation conditions, the amount of $\mathrm{C}_{18: 1} \omega 7 \mathrm{c} / 9 \mathrm{t} / 12 t$ was significantly lower in strain VC-230 ${ }^{\mathrm{T}}$ than in Sphingobium chlorophenolicum CCUG $56399^{\mathrm{T}}$ and Sphingobium herbicidovorans CCUG $56400^{\mathrm{T}}$ (45.9\% compared with approx. $54.5 \%$; Table 2).

Table 2. Cellular fatty acid compositions of strain $\mathrm{VC}-230^{\top}$, type strains of closely related species and the type strain of the type species of the genus Sphingobium

Strains: 1, Sphingobium vermicomposti sp. nov. VC- $230^{\mathrm{T}}$; 2, Sphingobium chlorophenolicum CCUG 56399 ; 3, Sphingobium herbicidovorans CCUG $56400^{\mathrm{T}}$; 4, Sphingobium yanoikuyae CCUG $28380^{\mathrm{T}}$. Data were taken from this study. Values are percentages of total fatty acids; only those present as $1.0 \%$ or more of the total are shown. - , Not detected or $<1 \%$.

\begin{tabular}{|lcccc|}
\hline Fatty acid & $\mathbf{1}$ & $\mathbf{2}$ & $\mathbf{3}$ & $\mathbf{4}$ \\
\hline $\mathrm{C}_{14: 0}$ & 1.2 & - & - & - \\
$\mathrm{C}_{14: 0} 2-\mathrm{OH}$ & 6.6 & 10.0 & 6.7 & 9.4 \\
$\mathrm{C}_{16: 1} \omega 7 c$ & 21.3 & 11.7 & 18.0 & 18.8 \\
$\mathrm{C}_{16: 1} \omega 5 c$ & - & 1.5 & 1.0 & 4.3 \\
$\mathrm{C}_{16: 0}$ & 13.7 & 13.3 & 12.4 & 12.4 \\
$\mathrm{C}_{17: 1} \omega 6 c$ & 2.2 & 2.4 & - & - \\
$\mathrm{C}_{18: 1} \omega 7 c / 9 t / 12 t$ & 45.9 & 54.9 & 53.9 & 51.1 \\
$\mathrm{C}_{18: 1} \omega 5 c$ & 1.7 & 2.5 & - & 4.1 \\
$11-$ Methyl $\mathrm{C}_{18: 1} \omega 7 c$ & 5.7 & 3.7 & 8.1 & - \\
Summed total & 99.2 & 100 & 100 & 100 \\
\hline
\end{tabular}

On the basis of the polyphasic characterization presented herein, a novel species, Sphingobium vermicomposti sp. nov., is proposed.

\section{Description of Sphingobium vermicomposti sp. nov.}

Sphingobium vermicomposti (ver.mi.com.pos'ti. L. masc. n. vermis worm; N.L. neut. n. compostum compost; N.L. gen. n. vermicomposti from compost produced by earthworms).

Colonies are yellow, circular and convex on PCA, LuriaBertani agar, tryptic soy agar and Mueller-Hinton agar. No growth is observed on m-faecal coliform (m-FC) medium. Cells are Gram-negative-staining rods $(0.95 \pm 0.23 \mu \mathrm{m}$ long and $0.44 \pm 0.07 \mu \mathrm{m}$ wide), motile by a polar flagellum. Strictly aerobic. Nitrate is not reduced. Catalase- and oxidase-positive. Growth occurs at $15-37{ }^{\circ} \mathrm{C}$ (optimum approx. $30^{\circ} \mathrm{C}$ ), at $\mathrm{pH} 6-8$ (optimum $\mathrm{pH}$ 7) and in the presence of $1 \% \mathrm{NaCl}$. Aesculin is hydrolysed. Produces $\beta$ galactosidase, $\beta$-glucosidase, esterase $(\mathrm{C} 4)$, esterase lipase (C8), leucine and valine arylamidases, trypsin, naphtholAS-BI-phosphohydrolase and acid and alkaline phosphatases. Arbutin, D-galactose, D-glucose, lactose and Lrhamnose are used as single carbon sources in the absence of organic growth factors. L-Arabinose is oxidized (API $20 \mathrm{E})$. Growth occurs with ( $\mu \mathrm{g}$ per disc) sulfamethoxazole/ trimethoprim (23.75/1.25) but not with amoxicillin (25), gentamicin (10), ciprofloxacin (5), tetracycline (30), cephalothin (30), meropenem (10), ceftazidime (30), ticarcillin (75) or colistin sulfate (50). The predominant fatty acids are $\mathrm{C}_{18: 1} \omega 7 c / 9 t / 12 t, \mathrm{C}_{16: 1}$ and $\mathrm{C}_{16: 0}$. The major respiratory quinone is $\mathrm{Q}-10$. The major polar lipids are phosphatidylglycerol, diphosphatidylglycerol, phosphatidyldimethylethanolamine, phosphatidylcholine and a sphingoglycolipid. Spermidine is produced. Hexachlorocyclohexane is not degraded. The DNA G $+\mathrm{C}$ content of the type strain is $62 \mathrm{~mol} \%$.

The type strain is $\mathrm{VC}-230^{\mathrm{T}}\left(=\mathrm{CCUG} 55809^{\mathrm{T}}=\mathrm{DSM}\right.$ $21299^{\mathrm{T}}$ ), isolated from homemade kitchen-waste vermicompost.

\section{Acknowledgements}

The authors acknowledge the technical assistance of Elisabeth Inganäs and Kent Molin for the determinations of the cellular fatty acids.

\section{References}

Barreiros, L., Nogales, B., Manaia, C. M., Ferreira, A. C. S., Pieper, D. H., Reis, M. A. \& Nunes, O. C. (2003). A novel pathway for mineralization of the thiocarbamate herbicide molinate by a defined bacterial mixed culture. Environ Microbiol 5, 944-953.

Busse, H.-J., Kämpfer, P. \& Denner, E. M. B. (1999). Chemotaxonomic characterisation of Sphingomonas. J Ind Microbiol Biotechnol 23, 242-251.

Epstein, E. (1997). The Science of Composting. Boca Raton, FL: CRC Press. 
Euzéby, J. P. (1997). List of bacterial names with standing in nomenclature: a folder available on the Internet. Int J Syst Bacteriol 47, 590-592 http://www.bacterio.cict.fr

Ferreira da Silva, M., Tiago, I., Veríssimo, A., Boaventura, A. R., Nunes, O. C. \& Manaia, C. M. (2006). Antibiotic resistance of enterococci and related bacteria in an urban wastewater treatment plant. FEMS Microbiol Ecol 55, 322-329.

Ferreira da Silva, M., Vaz-Moreira, I., Gonzalez-Pajuelo, M., Nunes, O. C. \& Manaia, C. M. (2007). Antimicrobial resistance patterns in Enterobacteriaceae isolated from an urban wastewater treatment plant. FEMS Microbiol Ecol 60, 166-176.

Fujii, K., Urano, N., Ushio, H., Satomi, M. \& Kimura, S. (2001). Sphingomonas cloacae sp. nov., a nonylphenol-degrading bacterium isolated from wastewater of a sewage-treatment plant in Tokyo. Int $J$ Syst Evol Microbiol 51, 603-610.

Hamana, K., Sakane, T. \& Yokota, A. (1994). Polyamine analysis of the genera Aquaspirillum, Magnetospirillum, Oceanospirillum and Spirillum. J Gen Appl Microbiol 40, 75-82.

Jukes, T. H. \& Cantor, C. R. (1969). Evolution of protein molecules. In Mammalian Protein Metabolism, vol. 3, pp. 21-132. Edited by H. N. Munro. New York: Academic Press.

Manaia, C. M., Nogales, B., Weiss, N. \& Nunes, O. C. (2004). Gulosibacter molinativorax gen. nov., sp. nov., a molinate-degrading bacterium, and classification of 'Brevibacterium helvolum' DSM 20419 as Pseudoclavibacter helvolus gen. nov., sp. nov. Int J Syst Evol Microbiol 54, 783-789.

Mesbah, M., Premachandran, U. \& Whitman, W. B. (1989). Precise measurement of the $\mathrm{G}+\mathrm{C}$ content of deoxyribonucleic acid by highperformance liquid chromatography. Int J Syst Bacteriol 39, 159-167.

Murray, R. G. E., Doetsch, R. N. \& Robinow, F. (1994). Determinative and cytological light microscopy. In Methods for General and Molecular Bacteriology, pp. 21-41. Edited by P. Gerhardt, R. G. E. Murray, W. A. Wood \& N. R. Krieg. Washington, DC: American Society for Microbiology.

Nohynek, L. J., Suhonen, E. L., Nurmiaho-Lassila, E. L., Hantula, J. \& Salkinoja-Salonen, M. (1995). Description of four pentachlorophenol-degrading bacterial strains as Sphingomonas chlorophenolica sp. nov. Syst Appl Microbiol 18, 527-538.
Smibert, R. M. \& Krieg, N. R. (1994). Phenotypic characterization. In Methods for General and Molecular Bacteriology, pp. 607-654. Edited by P. Gerhardt, R. G. E. Murray, W. A. Wood \& N. R. Krieg. Washington, DC: American Society for Microbiology.

Stackebrandt, E. \& Ebers, J. (2006). Taxonomic parameters revisited: tarnished gold standards. Microbiol Today 33, 152-155.

Takeuchi, M., Hamana, K. \& Hiraishi, A. (2001). Proposal of the genus Sphingomonas sensu stricto and three new genera, Sphingobium, Novosphingobium and Sphingopyxis, on the basis of phylogenetic and chemotaxonomic analyses. Int J Syst Evol Microbiol 51, 14051417.

Tindall, B. J. (1989). Fully saturated menaquinones in the archaebacterium Pyrobaculum islandicum. FEMS Microbiol Lett 60, 251-254.

Urdiain, M., López-López, A., Gonzalo, C., Busse, H.-J., Langer, S., Kämpfer, P. \& Rosselló-Móra, R. (2008). Reclassification of Rhodobium marinum and Rhodobium pfennigii as Afifella marina gen. nov. comb. nov. and Afifella pfennigii comb. nov., a new genus of photoheterotrophic Alphaproteobacteria and emended descriptions of Rhodobium, Rhodobium orientis and Rhodobium gokarnense. Syst Appl Microbiol 31, 339-351.

Vaz-Moreira, I., Nobre, M. F., Nunes, O. C. \& Manaia, C. M. (2007). Gulbenkiania mobilis gen. nov., sp. nov., isolated from treated municipal wastewater. Int J Syst Evol Microbiol 57, 1108-1112.

Vaz-Moreira, I., Silva, E., Manaia, C. M. \& Nunes, O. C. (2008). Diversity of bacterial isolates from commercial and homemade composts. Microb Ecol 55, 714-722.

Yabuuchi, E., Kosako, Y., Fugiwara, N., Naka, T., Matsunaga, I., Ogura, H. \& Kobayashi, K. (2002). Emendation of the genus Sphingomonas Yabuuchi et al. 1990 and junior objective synonymy of the species of three genera, Sphingobium, Novosphingobium and Sphingopyxis, in conjunction with Blastomonas ursincola. Int J Syst Evol Microbiol 52, 1485-1496.

Zipper, C., Nickel, K., Angst, W. \& Kohler, H. P. E. (1996). Complete microbial degradation of both enantiomers of the chiral herbicide mecoprop [ $R S)$-2-(4-chloro-2-methylphenoxy)propionic acid] in an enantioselective manner by Sphingomonas herbicidovorans sp. nov. Appl Environ Microbiol 62, 4318-4322. 